\title{
Roles of Beta2- and Beta3-Adrenoceptor Polymorphisms in Hypertension and Metabolic Syndrome
}

\author{
Kazuko Masuo \\ Nucleus Network Ltd. and Human Neurotransmitter Laboratory, Baker IDI Heart and Diabetes Research Institute, \\ 89 Commercial Road, Melbourne, VIC 3004, Australia \\ Correspondence should be addressed to Kazuko Masuo, kazuko.masuo@bakeridi.edu.au
}

Received 19 July 2010; Accepted 2 September 2010

Academic Editor: Toshio Ogihara

Copyright ( $(2010$ Kazuko Masuo. This is an open access article distributed under the Creative Commons Attribution License, which permits unrestricted use, distribution, and reproduction in any medium, provided the original work is properly cited.

Hypertension, diabetes mellitus (especially type 2 diabetes mellitus), metabolic syndrome and obesity are rapidly growing public health problems. Sympathetic nerve activation is observed in obesity, hypertension and diabetes mellitus, which have strong genetic as well as environmental determinants. Reduced energy expenditure and resting metabolic rate are predictive of weight gain, and the sympathetic nervous system participates in regulating energy balance through thermogenesis. The thermogenic effects of catecholamines in obesity have been mainly mediated via the $\beta 2$ - and $\beta 3$-adrenergic receptors in humans. Further, $\beta 2$-adrenoceptors importantly influence vascular reactivity and may regulate blood pressure. Genetic polymorphistns of the $\beta$-adrenoceptor gene have been shown to alter the function of several adrenoceptor subtypes and thus to modify the response to catecholamine. $\beta 2$-adrenoceptor polymorphisms (Arg16Gly, Gln27Glu, and Thr164Ile) have been studied in relation to hypertension. Genetic variations in the $\beta 3$-adrenoceptor (i.e. Try64Arg variant) are also associated with both obesity and hypertension. However, the precise relationships of the polymorphisms of $\beta 2$ - and $\beta 3$-adrenoceptor genes with sympathetic nervous system activity, hypertension, and metabolic syndrome have not been fully clarified. This paper will discuss the current topics involving the influence of the sympathetic nervous system and $\beta 2$ - and $\beta 3$-adrenoceptor polymorphisms in hypertension and metabolic syndrome.

\section{Introduction}

Obesity, hypertension, and metabolic syndrome (type 2 diabetes mellitus) are major and growing health problems and are known as high-risk factors for subsequent cardiovascular and renal complications [1-3]. Obesity, hypertension, diabetes, and metabolic syndrome are intimately associated [4-6], and sympathetic nervous activation is frequently observed in those conditions. Thus, sympathetic nerve activation may play a major role in the onset and development of hypertension, obesity, and metabolic syndrome (diabetes mellitus) as well as cardiovascular complications in patients with hypertension, diabetes and obesity $[2,7]$.

The sympathetic nervous system plays an important role in the regulation of energy expenditure. Reduced energy expenditure and resting metabolic rate are predictive of weight gain (obesity). The sympathetic nervous system participates in regulating energy balance through thermogenesis [8]. A large part of the sympathetic nervous systemmediated energy expenditure takes place in skeletal muscle, via the coupling of catecholamines with $\beta 2$-adrenoceptors. Catecholamines are also powerful regulators of lipolysis and act via $\beta 1-, \beta 2-, \beta 3-$ (stimulatory), and $\alpha 2$ - (inhibitory) adrenoceptor subtypes in adipose tissue, where their role becomes especially important during both exercise and energy restriction, when increased need for fat as a fuel exists. Thus, $\beta$-adrenoceptors play important roles in energy expenditure and control body weight [9-13].

Recently, there is evidence that human hypertension and obesity have strong genetic backgrounds [14-16]. Harrap et al. reported that about $46 \%$ of the phenotype of systolic blood pressure are determined genetically for hypertension $[17,18]$. Masuo et al. [18-22] have reported close relationships between $\beta 2$ - and $\beta 3$-adrenoceptor polymorphisms 
accompanying elevated sympathetic nervous activity, blood pressure elevation (hypertension), weight gain (obesity), and insulin resistance in a series of longitudinal study. Many epidemiological studies on the relationships between $\beta$-adrenoceptor polymorphisms, hypertension, obesity, and diabetes (metabolic syndrome) have still been discordant.

This paper will discuss the current topics involving the contribution of the sympathetic nervous system and $\beta 2$ - and $\beta 3$-adrenoceptor polymorphisms in the onset and the development of hypertension and metabolic syndrome (type 2 diabetes mellitus).

\section{Subtypes of Adrenoceptors (Table 1)}

The adrenoceptors (or adrenergic receptors) are a class of $\mathrm{G}$ protein-coupled receptors which specifically bind their endogenous ligands, the catecholamines (epinephrine and norepinephrine). Many tissues possess these adrenoceptors, and the binding of an agonist generally elicits a "typical" sympathetic response (i.e., the fight-or-flight response). Table 1 shows the effects of catecholamines bound to adrenoceptors (Table 1 ) and these effects on sympathetic nervous activity are through $\alpha$ - and $\beta$-adrenergic receptors.

There are several types of adrenergic receptors, but there are two main groups: $\alpha$-adrenoceptors $(\alpha 1-$ and $\alpha 2$ adrenoceptors) and $\beta$-adrenoceptors $(\beta 1-, \beta 2-$, and $\beta 3$ adrenoceptors). Table 1 also summaries the distributions and functions of the $\alpha 1-, \alpha 2-, \beta 1-, \beta 2-$, and $\beta 3$-adrenoceptors [24, $25]$. The $\alpha$-receptors bind norepinephrine and epinephrine, though norepinephrine has higher affinity. Phenylephrine is a selective agonist of the $\alpha$-adrenoceptors (both $\alpha 1$ and $\alpha 2$-receptors), thus phenylephrine is usually used to investigate the $\alpha$-adrenoceptors function. $\beta$-adrenoceptors are linked to $\mathrm{G}$ proteins, which are linked to adenyl cyclase. $\beta$ adrenoceptor agonists cause the intracellular elevation of the second messenger cyclic AMP. Downstream effects of cyclic AMP include cyclic AMP dependent protein kinase, which mediates the intracellular events following hormone binding.

\section{Sympathetic Nervous Activity and Insulin Resistance in Hypertension (Figure 1)}

Insulin resistance in hypertension has been well documented in many epidemiological and clinical studies [8, 26, 27]. Several investigators have reported that chronic insulin administration elevates blood pressure in rats and in humans [28], although insulin also has effects on vasodilation. In addition, many clinical and epidemiological studies have demonstrated the close relationships between sympathetic nerve activity, insulin resistance and hypertension [19, 2932].

Landsberg and other investigators examined the effect of feeding and starvation on sympathetic nerve activity in the cardiac tissue of animals, noting that feeding raised sympathetic nerve activity, and starvation had the opposite effect [33-35]. Energy intake stimulates hyperinsulinemia and sympathetic nerve activity resulting in blood pressure elevations in a cycle to inhibit thermogenesis. Insulinmediated sympathetic nerve stimulation in obese subjects is a compensatory mechanism aimed at restoring the energy balance by increasing the metabolic rate [33]. Therefore, hyperinsulinemia and insulin resistance in obese subjects are all part of a response to limit further weight gain via stimulating sympathetic nerve activity and thermogenesis [28].

On the other hand, Julius et al. [36] have hypothesized that increased sympathetic nerve activity in skeletal muscle causes neurogenic vasoconstriction, thereby reducing blood flow to muscle and consequently inducing a state of insulin resistance by lowering glucose delivery and uptake in hypertension and obesity. Both blood pressure elevation and weight gain may reflect a primary increase in sympathetic nervous tone. Masuo et al. [30, 37] supported Julius's hypothesis. They described that high plasma norepinephrine might predict future blood pressure elevations and weight gain accompanying deterioration in insulin resistance observed in HOMA-IR (homeostasis model assessments of insulin resistance) [30, 37]. Rocchini et al. [38] reported that clonidine prevented insulin resistance in obese dogs over a 6-week period. Their results suggest that sympathetic nerve activity might play a major role in the development of insulin resistance accompanying blood pressure elevations. Valentini et al. [39] reported attenuation of hemodynamic and energy expenditure responses to isoproterenol infusion in hypertensive patients, suggesting that sympathetic nerve activity-induced hypertension may subsequently lead to the development of obesity.

Many epidemiological studies showed close linkages of beta2- and beta3-adrenoceptor polymorphisms with obesity, hypertension, and the metabolic syndrome shown in Tables 2,3 , and 4. Sympathetic nervous activity is related to body weight or blood pressure through $\beta$-adrenoceptors. Thus, close linkages between sympathetic nerve activity and insulin resistance might depend on the $\beta$-adrenoceptor polymorphisms. Thus, one could speculate that the strong associations between $\beta$-adrenoceptor polymorphisms and insulin resistance might provide evidence that heightened sympathetic nerve activity followed by insulin resistance might play a major role in hypertension and obesity, because $\beta$-adrenoceptor polymorphisms might relate to insulin resistance through heightened sympathetic nerve activity (Figure 1).

\section{Role of $\beta$-Adrenoceptor Polymorphisms in Hypertension, Obesity, and Diabetes}

The sympathetic nervous system plays an important role in the regulation of energy expenditure and blood pressure regulation. A large part of the sympathetic nervous systemmediated energy expenditure takes place in skeletal muscle, via the coupling of catecholamines with $\beta 2$-adrenoceptors. Catecholamines are also powerful regulators of lipolysis and act via $\beta 1-, \beta 2-, \beta 3$ - (stimulatory), and $\alpha 2$ - (inhibitory) adrenoceptor subtypes in adipose tissue, where their role becomes especially important during both exercise and 
TABLE 1: Comparisons of adrenergic receptor subtypes.

\begin{tabular}{|c|c|c|c|}
\hline Receptor type & Agonist potency order & Action sites & Functions \\
\hline \multirow[t]{9}{*}{$\alpha 1$-adrenoceptor } & norepinephrine $\geq$ & $\begin{array}{c}\text { blood vessels of skim, gastrointestinal, } \\
\text { kidney }\end{array}$ & vasoconstriction \\
\hline & epinephrine $\gg$ & $\begin{array}{l}\text { ureter, uterus, urethral sphincter, } \\
\text { bronchioles }\end{array}$ & smooth muscle contraction, \\
\hline & isoprenaline & urinary bladder, & contraction, \\
\hline & & iris, blood vessels of erectile tissue, & smooth muscle relaxation, \\
\hline & & heart muscle, & positive ionotropic effect \\
\hline & & salivary gland, & increase in secretion, \\
\hline & & adiposetissue, liver & glycogenolysis and gluconeogenesis, \\
\hline & & sweat glands, & increase in secretion, \\
\hline & & kidneys & Na reabsorption \\
\hline \multirow[t]{3}{*}{$\alpha 2$-adrenoceptor } & epinephrine> & pancreas and & inhibition of insulin secretion, \\
\hline & norepinephrine $\ggg$ & & induction of glucagon release, and \\
\hline & isoprenaline & gastrointestinal tract & contraction of sphincters \\
\hline \multirow[t]{3}{*}{$\beta 1$-adrenoceptor } & isoprenaline > & heart, & increase cardiac output, \\
\hline & Norepinephrine $>$ & kidneys (juxtaglomerular cells), & increase renin release, and \\
\hline & Epinephrine & adipose tissue & lipolysis \\
\hline \multirow[t]{8}{*}{$\beta 2$-adrenoceptor } & isoprenaline > & Bronchi, & smooth muscle relaxation, \\
\hline & epinephrine» & urinary sphincter, bladder wall, & smooth muscle relaxation, \\
\hline & norepinephrine & skeletal muscle, & dilate arteries \\
\hline & & adipose tissue, liver & glycogenolysis and gluconeogenesis, \\
\hline & & gastrointestinal tract, & contract sphincters, \\
\hline & & salivary glands, & thickened secretions, \\
\hline & & mast cells, and & inhibit histamine release, and \\
\hline & & kidneys (juxtaglomerular cells) & increase renin release \\
\hline$\beta 3$-adrenoceptor & $\begin{array}{c}\text { isoprenaline }> \\
\text { norepinephrine }= \\
\text { epinephrine }\end{array}$ & adipose tissue & enhancement of lipolysis \\
\hline
\end{tabular}

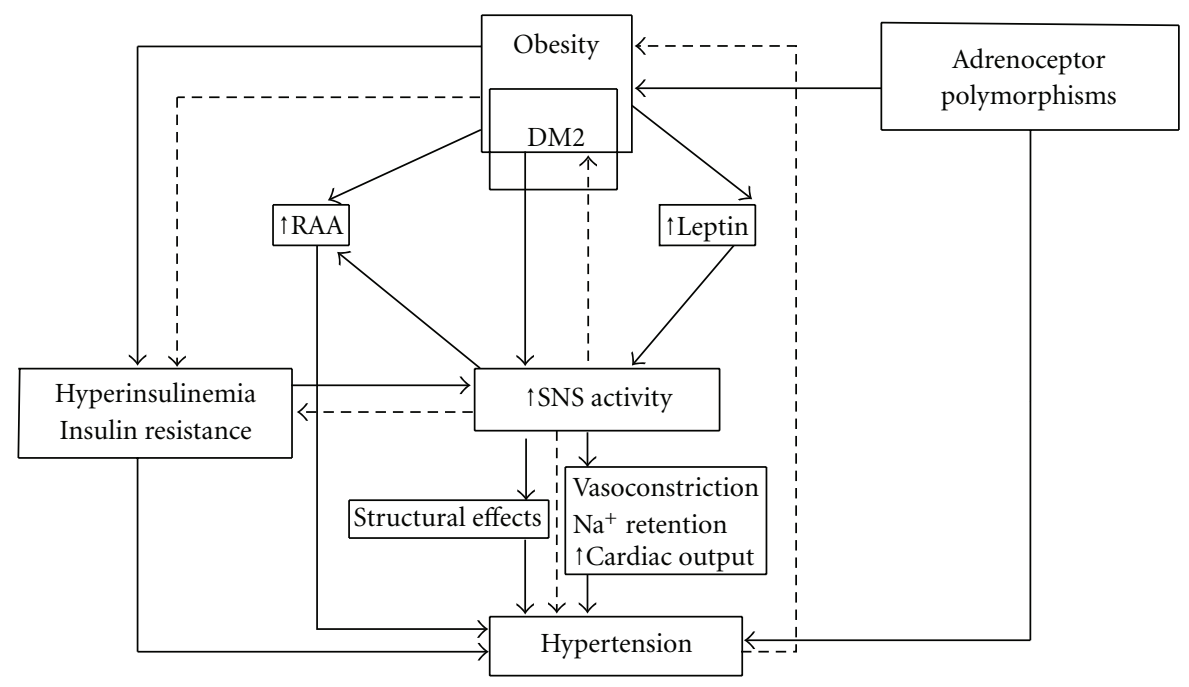

FIGURE 1: Potential pathophysiological mechanisms by which obesity may contribute to hypertension (modified figure from [23]). RAAS: renin-angiotensin-aldosterone system; SNS: sympathetic nervous system; OSA: obstructive sleep apnea; BRS, baroreflex sensitivity. 
TABLE 2: Arg16Gly, $\beta 2$-adrenoceptor polymorphisms: association with hypertension, metabolic syndrome (type2 diabetes: (DM)), and obesity.

\begin{tabular}{|c|c|c|c|c|}
\hline Authors & Year & Populations & Subjects & Associations with the polymorphism \\
\hline Large et al. [40] & 1997 & Swedish & $\begin{array}{l}140 \text { Caucasian women with a wide range } \\
\text { of obesity }\end{array}$ & Obesity \\
\hline The Quebec Family Study [41] & 2000 & Canada & Caucasian men and women & Obesity, hyperlipidemia \\
\hline Hayakawa et al. [42] & 2000 & Japanese & 210 Japanese men from a population & No association with obesity \\
\hline Jia et al. [43] & 2000 & USA & $\begin{array}{l}\text { Caucasians ( } 298 \text { hypertensive versus } 298 \\
\text { normotensive subjects) }\end{array}$ & No association with hypertension \\
\hline Xie et al. [44] & 2000 & USA & $\begin{array}{l}\text { Black and white Americans (including } \\
\text { normotensive and hypertensive subjects) }\end{array}$ & No associations with hypertension \\
\hline Candy et al. [45] & 2000 & English & $\begin{array}{l}\text { England Black African men (including } \\
192 \text { hypertensive and } 123 \text { normotensive } \\
\text { men) }\end{array}$ & No association with hypertension \\
\hline Cockcroft et al. [46] & 2000 & Caucasian & 127 young normotensive men & $\begin{array}{l}\text { Forearm vascular responses } \\
\text { (hypertension) }\end{array}$ \\
\hline Meirhaeghe et al. [47] & 2000 & French & $\begin{array}{l}1195 \text { middle-aged Caucasian from the } \\
\text { urban population }\end{array}$ & Obesity, if subjects carry Gln27Gln \\
\hline Kato et al. [48] & 2001 & Japanese & $\begin{array}{l}842 \text { hypertensive and } 633 \text { normotensive } \\
\text { subjects }\end{array}$ & $\begin{array}{l}\text { BP levels (hypertension) in } \\
\text { normotensives }\end{array}$ \\
\hline Bengtsson et al. [49] & 2001 & Swedish & $\begin{array}{l}\text { Hypertensive patients with and without } \\
\text { type } 2 \mathrm{DM}\end{array}$ & Hypertension in subjects with DM \\
\hline The Bogalusa Heart Study [50] & 2002 & USA & $\begin{array}{l}1151 \text { Caucasian and Black Africans } \\
\text { children (including boys and girls) }\end{array}$ & Weight gain in males \\
\hline Kim et al. [51] & 2002 & Korean & type $2 \mathrm{DM}$ patients & Obesity, DM, hyperlipidemia \\
\hline Chang et al. [52] & 2002 & Taiwanese & type $2 \mathrm{DM}$ patients & Type 2 DM \\
\hline Van Rossum et al. [53] & 2002 & Dutch & $\begin{array}{l}286 \text { subjects with a significant weight gain } \\
\text { over } 7 \text { years including men and women }\end{array}$ & $\begin{array}{l}\text { Weight gain in men, but not in } \\
\text { women }\end{array}$ \\
\hline The HERITAGE family study [54] & 2003 & Canada & Sedentary black and white women & Lower fat in obese white women \\
\hline Pereira et al. [20] & 2003 & Brazilian & $\begin{array}{l}1576 \text { ethnically mixed population } \\
\text { (including men and women) }\end{array}$ & Systolic BP, BMI \\
\hline The Olivetti heart study [55] & 2004 & Italian & $\begin{array}{l}993 \text { middle-aged men regardless of BP } \\
\text { levels or BMI }\end{array}$ & $\begin{array}{l}\text { No association with obesity or } \\
\text { hypertension }\end{array}$ \\
\hline Ikarashi et al. [56] & 2004 & Japanese & type 2 diabetic patients & Association with IR \\
\hline Tafel et al. [57] & 2004 & Germany & extremely obese children & No association with obesity \\
\hline Ellsworth et al. [58] & 2005 & USA & $\begin{array}{l}\text { Black and white American men and } \\
\text { women }\end{array}$ & BMI (obesity) in only men \\
\hline Trombetta et al. [59] & 2005 & Brazilian & Brazilian healthy women & $\begin{array}{l}\text { Hypertension (blunted forearm } \\
\text { vasodilation response) }\end{array}$ \\
\hline Masuo et al. [21] & 2005 & Japanese & Nonobese, normotensive men & $\begin{array}{l}\text { Weight gain, BP elevation, } \\
\text { obesity-HT }\end{array}$ \\
\hline Masuo et al. [60] & 2005 & Japanese & Nonobese, normotensive men & Insulin resistance \\
\hline Masuo et al. $[61,62]$ & 2006 & Japanese & $\begin{array}{l}\text { Normotensive men (including nonobese } \\
\text { and obese men) }\end{array}$ & $\begin{array}{l}\text { Weight gain, blunted } \\
\text { leptin-sympathetic axis }\end{array}$ \\
\hline Kurabayashi et al. [63] & 2006 & Japanese & PCOS patients & $\begin{array}{l}\text { Association with high prevalence of } \\
\text { PCOS Accompanying IR }\end{array}$ \\
\hline Gjesing et al. [64] & 2007 & Dutch & 7808 white subjects & $\begin{array}{l}\text { No association with hypertension or } \\
\text { obesity }\end{array}$ \\
\hline Masuo et al. [65] & 2007 & Japanese & 219 nonobese, normotensive men & $\begin{array}{l}\text { Association with high SNA followed } \\
\text { by IR }\end{array}$ \\
\hline
\end{tabular}

BP: blood pressure; BMI: body mass index; HT: hypertension; DM: diabetes mellitus; IR: insulin resistance; PCOS: polycystic ovary syndrome; SNA: sympathetic nervous activity. 
TABLe 3: Gln27Glu, $\beta 2$-adrenoceptor polymorphisms: association with hypertension, metabolic syndrome (type2 diabetes (DM)), and obesity.

\begin{tabular}{|c|c|c|c|c|}
\hline Authors [reference number] & Year & Populations & Subjects & Associations with the polymorphism \\
\hline Large et al. [40] & 1997 & Swedish & $\begin{array}{l}\text { Caucasian women with a wide } \\
\text { range of obesity }\end{array}$ & Association with obesity \\
\hline Echwald et al. [66] & 1998 & Danish & $\begin{array}{l}\text { Caucasian juvenile-onset obese } \\
\text { men }\end{array}$ & No association with obesity \\
\hline Hellström et al. [67] & 1999 & Swedish & Caucasian men and women & Association with obesity only in women \\
\hline Kortner et al. [68] & 1999 & German & Caucasian with morbid obesity & No association with obesity \\
\hline Xie et al. [44] & 2000 & USA & Black and white Americans & No associations with hypertension \\
\hline The Quebec Family Study [41] & 2000 & Canada & Caucasian men and women & $\begin{array}{l}\text { Association with obesity and } \\
\text { hyperlipidemia }\end{array}$ \\
\hline Hayakawa et al. [42] & 2000 & Japanese & $\begin{array}{l}210 \text { Japanese men from a } \\
\text { population }\end{array}$ & No association with obesity \\
\hline Candy et al. [45] & 2000 & England & $\begin{array}{l}\text { Black African men (including } \\
192 \text { hypertensive and } 123 \\
\text { normotensive men) }\end{array}$ & No association with hypertension \\
\hline Meirhaeghe et al. [47] & 2000 & French & $\begin{array}{l}1195 \text { middle-aged Caucasian in } \\
\text { the urban population }\end{array}$ & Association with obesity in men \\
\hline Kato et al. [48] & 2001 & Japanese & $\begin{array}{l}842 \text { hypertensive and } 633 \\
\text { normotensive subjects }\end{array}$ & $\begin{array}{l}\text { Association with BP levels } \\
\text { (hypertension) in NT }\end{array}$ \\
\hline Kawamura et al. [69] & 2001 & Japanese & Japanese-Americans & No association with obesity or DM \\
\hline Ukkola et al. [70] & 2002 & USA & 12 pairs of twins, Caucasians & Association with weight gain (obesity) \\
\hline Kim et al. [51] & 2002 & Korean & Patients with type $2 \mathrm{DM}$ & $\begin{array}{l}\text { Association with obesity, DM, and } \\
\text { hyperlipidemia }\end{array}$ \\
\hline Gonzalez-Sanchez et al. [71] & 2003 & Spanish & $\begin{array}{l}666 \text { Caucasian-based study } \\
\text { (including men and women) }\end{array}$ & Association with obesity only in men \\
\hline The HERITAGE family study [49] & 2003 & Canada & Sedentary black and white men & $\begin{array}{l}\text { Association with lower fat in obese } \\
\text { white men }\end{array}$ \\
\hline Pereira et al. [20] & 2003 & Brazilian & $\begin{array}{l}1576 \text { ethnically mixed } \\
\text { population (including men and } \\
\text { women) }\end{array}$ & No association with systolic BP or BMI \\
\hline The Olivetti heart study [55] & 2004 & Italian & $\begin{array}{l}993 \text { middle-aged men (regardless } \\
\text { of BP levels or BMI) }\end{array}$ & $\begin{array}{l}\text { No association with obesity or } \\
\text { hypertension }\end{array}$ \\
\hline Tafel et al. [57] & 2004 & Germany & Extremely obese children & No association with obesity \\
\hline Masuo et al. [21] & 2005 & Japanese & Nonobese, normotensive men & $\begin{array}{l}\text { Association with BP elevation, but no } \\
\text { association with IR }\end{array}$ \\
\hline Trombetta et al. [59] & 2005 & Brazilian & Brazilian healthy women & $\begin{array}{l}\text { Association with hypertension (blunted } \\
\text { forearm vasodilation response) }\end{array}$ \\
\hline Kurabayashi et al. [63] & 2006 & Japanese & PCOS women & $\begin{array}{l}\text { Association with high prevalence of } \\
\text { PCOS accompanying IR }\end{array}$ \\
\hline Gjesing et al. [64] & 2007 & Dutch & 7808 white subjects & $\begin{array}{l}\text { No association with hypertension or } \\
\text { obesity }\end{array}$ \\
\hline Masuo et al. [65] & 2007 & Japanese & $\begin{array}{l}219 \text { nonobese, normotensive } \\
\text { men }\end{array}$ & No association with IR \\
\hline
\end{tabular}

BP: blood pressure; BMI: body mass index; DM: diabetes mellitus; NIDDM: noninsulin-dependent diabetes mellitus; IR: insulin resistance; PCOS: polycystic ovary syndrome; NT: normotensive subjects.

energy restriction, when increased need for fat as a fuel exists. Stimulation of $\beta$-adrenergic receptors by the sympathetic nervous system is a significant physiological modulator of pre- and postprandial energy expenditure [11-13] and total daily energy expenditure $[9,10]$.

Recent studies show that $\beta$-adrenoceptors are polymorphic. Single nucleotide polymorphisms might have functional consequences in terms of receptor activity and regulation and hence may contribute to the pathophysiology of hypertension and obesity. On the other hand, there are few studies on the relationships between $\alpha$-adrenoceptor polymorphisms, hypertension, obesity, and metabolic syndrome.

4.1. $\beta 1$-Adrenoceptor Polymorphisms. The $\beta 1$-adrenoceptor is predominantly expressed in cardiac myocytes and adipose 
TABle 4: Trp64Arg, $\beta 3$-adrenoceptor polymorphisms: association with hypertension, metabolic syndrome (type2 diabetes (DM)), and obesity.

\begin{tabular}{|c|c|c|c|c|}
\hline $\begin{array}{l}\text { Authors [reference } \\
\text { number] }\end{array}$ & Year & Populations & Subjects & Associations with the polymorphism \\
\hline \multirow[t]{2}{*}{ Clement et al. [76] } & 1995 & French & $\begin{array}{l}185 \text { subjects with } \\
\text { morbid obesity and }\end{array}$ & Increased capacity of weight gain \\
\hline & & & $\begin{array}{l}94 \text { subjects with } \\
\text { normal weight }\end{array}$ & \\
\hline Widen et al. [77] & 1995 & Finns & $\begin{array}{l}335 \text { subjects including } \\
207 \text { non-DM and } 128 \\
\text { patients with NIDDM }\end{array}$ & Insulin resistance \\
\hline Walston et al. [78] & 1995 & Pima Indians & $\begin{array}{l}390 \text { with NIDDM and } \\
252 \text { without NIDDM }\end{array}$ & $\begin{array}{l}\text { Association with the early onset of } \\
\text { DM2 }\end{array}$ \\
\hline Fujisawa et al. [79] & 1996 & Japanese & Patients with NIDDM & Type 2 DM, weight gain (obesity) \\
\hline Silver et al. [80] & 1996 & Nauruans & $\begin{array}{l}65 \text { obese subjects with } \\
\text { NIDDM }\end{array}$ & No association with DM2 or IR \\
\hline Fujisawa et al. [81] & 1997 & Japanese & $\begin{array}{l}\text { Essential } \\
\text { hypertension patients }\end{array}$ & $\begin{array}{l}\text { No association with IR during } \\
\text { hyperinsulinemia euglycemic glucose } \\
\text { clamp }\end{array}$ \\
\hline Sakane et al. [82] & 1997 & Japanese & $\begin{array}{l}131 \text { obese women } \\
\text { versus } 218 \text { controls }\end{array}$ & Association with IR and obesity \\
\hline Rissanen et al. [83] & 1997 & Finns & $\begin{array}{l}110 \text { with NIDDM, } \\
183 \text { with IR, and } 82 \\
\text { controls }\end{array}$ & No association with NIDDM or IR \\
\hline $\begin{array}{l}\text { McFarlane-Anderson } \\
\text { et al. [84] }\end{array}$ & 1998 & Jamaican & Population study & $\begin{array}{l}\text { Association with hyperglycemia only } \\
\text { in women, but not in men }\end{array}$ \\
\hline $\begin{array}{l}\text { Gracía-Rubi et al. } \\
{[85]}\end{array}$ & 1998 & American & $\begin{array}{l}\text { Postmenopausal } \\
\text { women }\end{array}$ & Association with IR \\
\hline Janssen et al. [86] & 1998 & Dutch & $\begin{array}{l}\text { Postmenopausal } \\
\text { women }\end{array}$ & Association with IR \\
\hline Shiwaku et al. [87] & 1998 & Japanese & $\begin{array}{l}\text { Moderate overweight } \\
\text { men }\end{array}$ & No association with obesity \\
\hline $\begin{array}{l}\text { Ongphiphadhanakul } \\
\text { et al. [88] }\end{array}$ & 1999 & Thais & $\begin{array}{l}76 \text { men and } 135 \\
\text { women }\end{array}$ & $\begin{array}{l}\text { No association with IR assessed by } \\
\text { fasting insulin/glucose ratio }\end{array}$ \\
\hline Pulkkinen et al. [89] & 1999 & Finns & $\begin{array}{l}185 \text { untreated } \\
\text { non-DM and } 119 \\
\text { untreated NIDDM }\end{array}$ & $\begin{array}{l}\text { No association with IR or CHD in } \\
\text { both non-DM and NIDDM }\end{array}$ \\
\hline $\begin{array}{l}\text { Christiansen et al. } \\
{[90]}\end{array}$ & 1999 & Danish & 196 dizygotic twins & $\begin{array}{l}\text { Association with lower insulin } \\
\text { secreting capacity }\end{array}$ \\
\hline Kawamura et al. [69] & 1999 & $\begin{array}{l}\text { Japanese- } \\
\text { American }\end{array}$ & $\begin{array}{l}\text { Japanese living in } \\
\text { USA versus living in } \\
\text { Japan }\end{array}$ & $\begin{array}{l}\text { Similar distribution between } \\
\text { Japanese-America and } \\
\text { Japanese-Japanese. Association with } \\
\text { IR in subjects with impaired oral } \\
\text { glucose tolerance test. }\end{array}$ \\
\hline Stangl et al. [91] & 2001 & German & $\begin{array}{l}1000 \text { with } \mathrm{CHD} \text { and } \\
1000 \text { controls }\end{array}$ & $\begin{array}{l}\text { No association with prevalence of } \\
\text { CHD or IR }\end{array}$ \\
\hline $\begin{array}{l}\text { Strazzullo et al. [92] } \\
\text { (The Olivetti } \\
\text { Prospective Heart } \\
\text { Study) }\end{array}$ & 2001 & Italian & 979 population study & $\begin{array}{l}\text { No association with IR observed in } \\
\text { HOMA-IR }\end{array}$ \\
\hline Ishii et al. [93] & 2001 & Japanese & $\begin{array}{l}196 \text { young } \\
\text { normoglycemic men, } \\
186 \text { old } \\
\text { normoglycemic men, } \\
\text { and } 122 \text { old } \\
\text { hyperglycaemic men }\end{array}$ & No association with IR or NIDDM \\
\hline Kurokawa et al. [94] & 2001 & Japanese & $\begin{array}{l}\text { meta-analysis in } 6582 \\
\text { subjects }\end{array}$ & BMI (obesity) \\
\hline
\end{tabular}


Table 4: Continued.

\begin{tabular}{|c|c|c|c|c|}
\hline $\begin{array}{l}\text { Authors [reference } \\
\text { number] }\end{array}$ & Year & Populations & Subjects & Associations with the polymorphism \\
\hline Ochoa et al. [95] & 2004 & Spanish & $\begin{array}{l}185 \text { obese and } 185 \\
\text { nonobese children }\end{array}$ & BMI (obesity) \\
\hline Porto et al. [96] & 2004 & Argentina & $\begin{array}{l}121 \mathrm{NT} \text { and } 54 \mathrm{HT} \\
\text { from } 934 \text { high school } \\
\text { students }\end{array}$ & $\begin{array}{l}\text { Association with central obesity, but } \\
\text { no association with IR }\end{array}$ \\
\hline Tsai et al. [97] & 2004 & Taiwanese & 299 pregnant women & No association with gestational IR \\
\hline Ellsworth et al. [58] & 2005 & USA & $\begin{array}{l}1179 \\
\text { African-Americans } \\
\text { and white-Americans }\end{array}$ & BMI (obesity) \\
\hline Masuo K, et al. [21] & 2005 & Japanese & $\begin{array}{l}\text { Nonobese, } \\
\text { normotensive men }\end{array}$ & BP elevation \\
\hline Masuo et al. [62] & 2006 & Japanese & $\begin{array}{l}55 \text { obese } \\
\text { normotensive men }\end{array}$ & $\begin{array}{l}\text { Weight gain (obesity), BP elevation } \\
\text { (hypertension) }\end{array}$ \\
\hline Højlund et al. [98] & 2006 & Danish & 10 male twins & $\begin{array}{l}\text { No association between heterozygous } \\
\text { for Trp64Arg and IR or NIDDM }\end{array}$ \\
\hline Tamaki et al. [99] & 2006 & Japanese & $\begin{array}{l}1416 \text { population } \\
\text { study without HT, } \\
\text { DM, or } \\
\text { hyperlipidemia }\end{array}$ & $\begin{array}{l}\text { No association with metabolic } \\
\text { syndrome }\end{array}$ \\
\hline Morcillo et al. [100] & 2008 & Spanish & $\begin{array}{l}1020 \text { population } \\
\text { study }\end{array}$ & $\begin{array}{l}\text { Join association of alleles of }-75 \mathrm{~A} \text { and } \\
\text { Arg64 with the risk of DM }\end{array}$ \\
\hline Gjesing et al. [101] & 2008 & Danish & $\begin{array}{l}7605 \text { population } \\
\text { study }\end{array}$ & $\begin{array}{l}\text { Association with NIDDM and IR, } \\
\text { but no association with obesity }\end{array}$ \\
\hline Dunajska et al. [102] & 2008 & Polish & $\begin{array}{l}284 \text { postmenopausal } \\
\text { women }\end{array}$ & $\begin{array}{l}\text { No association with metabolic } \\
\text { syndrome }\end{array}$ \\
\hline
\end{tabular}

BP: blood pressure; BMI: body mass index; DM: diabetes mellitus; NIDDM: noninsulin-dependent diabetes mellitus; DM2: type 2 diabetes mellitus; IR: insulin resistance.

TABLE 5: Confounding variables considered to cause the discrepancy of the relationships between $\beta$-adrenoceptor polymorphisms and phenotypes of hypertension and metabolic syndrome in obesity.

\begin{tabular}{ll}
$\begin{array}{l}\text { Variables [reference } \\
\text { number] }\end{array}$ & Findings in the studies \\
\hline $\begin{array}{l}\text { Severity of obesity } \\
{[16,57,62,76,95]}\end{array}$ & $\begin{array}{l}\text { In lean subjects, } \beta 2 \text {-AR polymorphisms linked to obesity and obesity-related hypertension, but in } \\
\text { obese subjects, } \beta 2 \text { - and } \beta 3 \text {-AR polymorphisms relate to obesity and obesity-related hypertension. } \\
\text { Morbid obesity is linked with } \beta 3 \text {-AR polymorphisms, but overweight or mild obesity is not associated } \\
\text { with those. }\end{array}$ \\
\hline $\begin{array}{l}\text { Gender differences [71] } \\
\text { Interaction between } \beta 1 \text { - and } \beta 2 \text {-AR polymorphisms with changes in BMI was observed in men only, } \\
\text { while in women an interaction between } \beta 1 \text { - and } \beta 3 \text {-AR polymorphisms was observed in a longitudinal } \\
\text { over a } 24 \text {-year period large cohort study. }\end{array}$ \\
\hline $\begin{array}{l}\text { Haplotype difference }[103,104] \\
{[20,58,59,105-107]}\end{array}$ & Distributions of $\beta$-AR polymorphisms are different in 8 different ethnic populations. \\
\hline AR & Functions expressed of $\beta$-AR polymorphisms are different due to the other $\beta$-AR polymorphisms. \\
\hline
\end{tabular}

AR: adrenoceptor; BMI: body mass index.

tissue, where its activation leads to increased heart rate and contractility and stimulation of lipolysis, respectively. The two most common $\beta 1$-adrenoceptor polymorphisms are Ser49Gly and Arg389Gly, with relative allele frequencies of $0.85 / 0.15$ and $0.70 / 0.30$ in the Caucasian population, respectively. The $\beta 1$-adrenoceptor is a candidate gene for obesity because of its role in catecholamine-mediated energy homeostasis $[72,73]$. For example, in obese individuals, the degree of weight loss during a very low calorie diet has been shown to correlate with changes in $\beta 1$-adrenoceptor protein concentration in adipose tissue [72]. A population cohort of 761 women showed that women carrying the Gly49 genotype had greater increases in BMI over15 years compared to those with the Ser49 genotype [73]. Conversely, the distribution of the Arg389Gly polymorphism is similar in lean and obese subjects [74] and in a large cohort study including 3981 normotensive and 2518 hypertensive subjects [75]. The factors which might explain the discrepancy of published data are shown in the later section. 
4.2. $\beta 2$-Adrenoceptor Polymorphisms. The $\beta 2$-adrenoceptor is the dominant lipolytic receptor in white human adipose tissue [13] and in skeletal muscle [12]. It also plays an important regulatory role in the peripheral vasculature. Genetic polymorphisms of the $\beta 2$-adrenoceptor have been associated with hypertension, obesity, and metabolic syndrome (diabetes mellitus). The most common polymorphisms are Arg16Gly, with an allele frequency of $0.40 / 0.60$, and Gln27Glu, with an allele frequency of $0.55 / 0.45$, in the Caucasian population. The Thr164Ile polymorphism is rare, occurring in only 3 to $5 \%$ of the general Caucasians population.

Studies of agonist stimulation in cultured cells demonstrate that Gly16 receptors have a greater reduction in numbers or enhanced downregulation when compared with Arg16 whereas the Glu27 receptor is resistant to down regulation when compared with the Gln27 variant [108]. A number of clinical studies have investigated the impact of these polymorphisms on vascular responsiveness [40, 109]. Gratze et al. [110] found that young normotensive white men homozygous for the Gly16 allele had higher blood pressure and lower peripheral vasodilation after infusion of the $\beta 2$ agonist salbutamol. Similar results were obtained by Hoit et al. [111] using the agonist terbutaline. On the other hand, three studies investigating isoprenaline induced increase in the limb blood flow Thus, volunteers homozygous for Gly16 exhibited larger vasodilatory responses than did volunteers homozygous for Arg16 [23]. Conflicting results have also been published with regard to the effects of genetic variants on the sympathetic nervous system modulation of energy expenditure. Bell et al. [112] reported that the response of resting energy expenditure to nonspecific $\beta$-adrenoceptor stimulation (with isoproterenol infusion) was not different between the 3 genotypes of Arg16Gly. Stob et al. [41] showed that individuals carrying the Arg16Arg variant of the $\beta 2$ adrenoceptor gene have a reduced thermogenic response to selective $\beta 2$-adrenoceptor activation.

Associations of $\beta 2$-adrenoceptor polymorphisms with hypertension and metabolic syndrome have been reported in many epidemiological studies but results are also discordant (summarised in Tables 2 and 3 ).

4.3. $\beta 3$-Adrenoceptor Polymorphisms. The $\beta 3$-adrenoceptor, which is mainly expressed in adipose tissue, differs from the $\beta 2$-adrenoceptor in two ways: it has a lower affinity for catecholamines, and it resists desensitisation (i.e., downregulation). These characteristic differences might lead to the different effects of catecholamine on $\beta 2$-adrenoceptors and $\beta 3$-adrenoceptors. $\beta 3$-adrenoceptors stimulate the mobilization of lipids from the white fat cell and increase thermogenesis in brown fat cell. Decreased function of $\beta 3$ adrenoceptor in white adipose tissue could slow lipolysis and thereby cause the retention of lipids in fat cells. Slow lipolysis may contribute strongly to visceral obesity in human, and treatment of obese animal models with selective $\beta 3$-adrenergic agonists reduces fat stores most effectively $[94,113,114]$. Many epidemiological studies have shown the strong relationships between $\beta 3$-adrenoceptor polymorphisms (mainly Trp54Arg), hypertension, metabolic syndrome, and obesity [78, 94, 113-117] (Table 4).

4.4. Confounding Variables Affecting the Relationships of $\beta$-Adrenoceptor Polymorphisms with Obesity, Hypertension, and Diabetes (Table 5). Tables 2, 3, 4, and 5 show the discordant contributions of $\beta$-adrenoceptor polymorphisms to hypertension, metabolic syndrome (type 2 diabetes), and obesity. Table 5 summarizes factors which might explain the discrepancy of published data. Further, haplotypes of polymorphisms have strong influence on $\beta$-adrenoceptor function in each polymorphism [20, 58, 59, 105-107].

\section{Conclusions}

The role of the sympathetic nervous system $\beta 2$ - and $\beta 3$ adrenoceptor polymorphisms in hypertension, metabolic syndrome (diabetes mellitus), and obesity is discussed through a literature review. Sympathetic nervous system activity and $\beta$-adrenoceptor polymorphisms (mainly $\beta 2$ and $\beta 3$-adrenoceptor polymorphisms) might contribute to the onset and maintenance of hypertension, metabolic syndrome, and obesity; however, the findings have been discordant. Further, few studies have been performed to evaluate the relationship between $\beta 2$ - and $\beta 3$-adrenoceptor polymorphisms and sympathetic nervous system activity in the same study. A better understanding for the relationships of genetic background (polymorphisms) with sympathetic nervous system activity as the cause for hypertension (blood pressure elevation), metabolic syndrome (insulin resistance), and obesity (weight gain) might help for clinical treatment for obesity-related hypertension and metabolic syndrome. In fact, a number of studies have investigated genetic polymorphisms as determinants of cardiovascular response to antihypertensive drug therapy [103, 104]. But further research on gene-drug interactions is necessary. In addition, to clarify the pathogenesis and mechanisms may lead to the prevention of hypertension and metabolic syndrome in obesity.

\section{References}

[1] A. H. Mokdad, B. A. Bowman, E. S. Ford, F. Vinicor, J. S. Marks, and J. P. Koplan, "The continuing epidemics of obesity and diabetes in the United States," Journal of the American Medical Association, vol. 286, no. 10, pp. 11951200, 2001.

[2] C. Heidemann, H. Boeing, T. Pischon, U. Nöthlings, H.-G. Joost, and M. B. Schulze, "Association of a diabetes risk score with risk of myocardial infarction, stroke, specific types of cancer, and mortality: a prospective study in the European Prospective Investigation into Cancer and Nutrition (EPIC)Potsdam cohort," European Journal of Epidemiology, vol. 24, no. 6, pp. 281-288, 2009.

[3] K. M. Flegal, B. I. Graubard, D. F. Williamson, and M. H. Gail, "Cause-specific excess deaths associated with underweight, overweight, and obesity," Journal of the American Medical Association, vol. 298, no. 17, pp. 2028-2037, 2007. 
[4] F. Ramsey, A. Ussery-Hall, D. Garcia et al., "Centers for disease control and prevention (CDC)," MMWR Surveillance Summaries, vol. 57, pp. 1-20, 2008.

[5] C. L. Ogden, C. D. Fryar, M. D. Carroll, and K. M. Flegal, "Advance data from vital and health statics," CDC, vol. 347, pp. 1-20, 2004.

[6] A. H. Mokdad, M. K. Serdula, W. H. Dietz, B. A. Bowman, J. S. Marks, and J. P. Koplan, "The spread of the obesity epidemic in the United States, 1991-1998," Journal of the American Medical Association, vol. 282, no. 16, pp. 15191522, 1999.

[7] S. R. Preis, S.-J. Hwang, S. Coady et al., "Trends in all-cause and cardiovascular disease mortality among women and men with and without diabetes mellitus in the Framingham heart study, 1950 to 2005," Circulation, vol. 119, no. 13, pp. 17281735, 2009.

[8] M. Spraul, E. Ravussin, A. M. Fontvieille, R. Rising, D. E. Larson, and E. A. Anderson, "Reduced sympathetic nervous activity. A potential mechanism predisposing to body weight gain," Journal of Clinical Investigation, vol. 92, no. 4, pp. 1730-1735, 1993.

[9] S. Iwashita, M. Tanida, N. Terui et al., "Direct measurement of renal sympathetic nervous activity in high-fat diet-related hypertensive rats," Life Sciences, vol. 71, no. 5, pp. 537-546, 2002.

[10] M. B. Monroe, D. R. Seals, L. F. Shapiro, C. Bell, D. Johnson, and P. P. Jones, "Direct evidence for tonic sympathetic support of resting metabolic rate in healthy adult humans," American Journal of Physiology, vol. 280, no. 5, pp. E740 E744, 2001.

[11] E. E. Blaak, M. A. van Baak, K. P. G. Kempen, and W. H. M. Saris, "Role of $\alpha$ - and $\beta$-adrenoceptors in sympathetically mediated thermogenesis," American Journal of Physiology, vol. 264, no. 1, pp. E11-E17, 1993.

[12] E. Hagström-Toft, S. Enoksson, E. Moberg, J. Bolinder, and P. Arner, " $\beta$-adrenergic regulation of lipolysis and blood flow in human skeletal muscle in vivo," American Journal of Physiology, vol. 275, no. 6, pp. E909-E916, 1998.

[13] S. Enoksson, M. Talbot, F. Rife, W. V. Tamborlane, R. S. Sherwin, and S. Caprio, "Impaired in vivo stimulation of lipolysis in adipose tissue by selective $\beta 2$-adrenergic agonist in obese adolescent girls," Diabetes, vol. 49, no. 12, pp. 2149 2153, 2000.

[14] K. Masuo, H. Mikami, T. Ogihara, and M. L. Tuck, "Familial hypertension, insulin, sympathetic activity, and blood pressure elevation," Hypertension, vol. 32, no. 1, pp. 96-100, 1998.

[15] K. Masuo, H. Mikami, T. Ogihara, and M. L. Tuck, "Familial obesity, sympathetic activation and blood pressure level," Blood Pressure, vol. 10, no. 4, pp. 199-204, 2001.

[16] J. Cui, J. L. Hopper, and S. B. Harrap, "Genes and family environment explain correlations between blood pressure and body mass index," Hypertension, vol. 40, no. 1, pp. 7-12, 2002.

[17] J. Cui, J. L. Hopper, and S. B. Harrap, "Genes and family environment explain correlations between blood pressure and body mass index," Hypertension, vol. 40, no. 1, pp. 7-12, 2002.

[18] K. J. Scurrah, S. G. Zaloumis, J. L. Hopper, and S. B. Harrap, "Contribution of genes and environment to variation in postural changes in mean arterial and pulse pressure," Journal of Hypertension, vol. 26, no. 12, pp. 2319-2325, 2008.

[19] K. Masuo, H. Mikami, T. Ogihara, and M. L. Tuck, "Differences in insulin and sympathetic responses to glucose ingestion due to family history of hypertension," American Journal of Hypertension, vol. 9, no. 8, pp. 739-745, 1996.

[20] A. C. Pereira, M. S. Floriano, G. F. A. Mota et al., " $\beta 2$ adrenoceptor functional gene variants, obesity, and blood pressure level interactions in the general population," Hypertension, vol. 42, no. 4, pp. 685-692, 2003.

[21] K. Masuo, T. Katsuya, Y. Fu, H. Rakugi, T. Ogihara, and M. L. Tuck, " $\beta 2$ - and $\beta 3$-adrenergic receptor polymorphisms are related to the onset of weight gain and blood pressure elevation over 5 years," Circulation, vol. 111, no. 25, pp. 34293434, 2005.

[22] K. Masuo, T. Katsuya, H. Kawaguchi et al., "Rebound weight gain as associated with high plasma norepinephrine levels that are mediated through polymorphisms in the $\beta 2$ adrenoceptor," American Journal of Hypertension, vol. 18, no. 11, pp. 1508-1516, 2005.

[23] K. Leineweber, "Beta-adrenergic receptor polymorphism in human cardiovascular disease," Annals of Medicine, vol. 36, no. 1, pp. 64-69, 2004.

[24] L. T. Jablonskis and P. R. C. Howe, "Lack of influence of circulating adrenaline on blood pressure in normotensive and hypertensive rats," Blood Pressure, vol. 3, no. 1-2, pp. 112-119, 1994.

[25] M. Dóda, "Role of different subtypes of adrenoceptors in pressor responses to catecholamines released from sympathetic nerve endings," Brain Research Bulletin, vol. 42, no. 1, pp. 51-57, 1996.

[26] E. Ferrannini, G. Buzzigoli, and R. Bonadonna, "Insulin resistance in essential hypertension," The New England Journal of Medicine, vol. 317, no. 6, pp. 350-357, 1987.

[27] K. Masuo, H. Mikami, T. Ogihara, and M. L. Tuck, "Prevalence of hyperinsulinemia in young, nonobese Japanese men," Journal of Hypertension, vol. 15, no. 2, pp. 157-165, 1997.

[28] L. Landsberg, "Insulin-mediated sympathetic stimulation: role in the pathogenesis of obesity-related hypertension (or, how insulin affects blood pressure, and why)," Journal of Hypertension, vol. 19, no. 3, pp. 523-528, 2001.

[29] K. D. Ward, D. Sparrow, L. Landsberg, J. B. Young, P. S. Vokonas, and S. T. Weiss, "Influence of insulin, sympathetic nervous system activity, and obesity on blood pressure: the Normative Aging Study," Journal of Hypertension, vol. 14, no. 3, pp. 301-308, 1996.

[30] K. Masuo, H. Kawaguchi, H. Mikami, T. Ogihara, and M. L. Tuck, "Serum uric acid and plasma norepinephrine concentrations predict subsequent weight gain and blood pressure elevation," Hypertension, vol. 42, no. 4, pp. 474-480, 2003.

[31] K. Masuo, "Obesity-related hypertension: role of the sympathetic nervous system, insulin, and leptin," Current Hypertension Reports, vol. 4, no. 2, pp. 112-118, 2002.

[32] N. E. Straznicky, E. A. Lambert, G. W. Lambert, K. Masuo, M. D. Esler, and P. J. Nestel, "Effects of dietary weight loss on sympathetic activity and cardiac risk factors associated with the metabolic syndrome," Journal of Clinical Endocrinology and Metabolism, vol. 90, no. 11, pp. 5998-6005, 2005.

[33] L. Landsberg, "Diet, obesity and hypertension: an hypothesis involving insulin, the sympathetic nervous system, and adaptive thermogenesis," Quarterly Journal of Medicine, vol. 61, no. 236, pp. 1081-1090, 1986.

[34] L. Landsberg and J. B. Young, "Fasting, feeding and regulation of the sympathetic nervous system," The New England Journal of Medicine, vol. 298, no. 23, pp. 1295-1301, 1978. 
[35] K. O’Dea, M. Esler, and P. Leonard, "Noradrenaline turnover during under- and over-eating in normal weight subjects," Metabolism, vol. 31, no. 9, pp. 896-899, 1982.

[36] S. Julius, M. Valentini, and P. Palatini, "Overweight and hypertension: a 2-way street?” Hypertension, vol. 35, no. 3, pp. 807-813, 2000.

[37] K. Masuo, H. Mikami, M. Itoh, T. Ogihara, and M. L. Tuck, "Sympathetic activity and body mass index contribute to blood pressure levels," Hypertension Research, vol. 23, no. 4, pp. 303-310, 2000.

[38] A. P. Rocchini, H. Z. Mao, K. Babu, P. Marker, and A. J. Rocchini, "Clonidine prevents insulin resistance and hypertension in obese dogs," Hypertension, vol. 33, no. 1, pp. 548-553, 1999.

[39] M. Valentini, S. Julius, P. Palatini et al., "Attenuation of haemodynamic, metabolic and energy expenditure responses to isoproterenol in patients with hypertension," Journal of Hypertension, vol. 22, no. 10, pp. 1999-2006, 2004.

[40] V. Large, L. Hellström, S. Reynisdottir et al., "Human beta2 adrenoceptor gene polymorphisms are highly frequent in obesity and associate with altered adipocyte beta-2 adrenoceptor function," Journal of Clinical Investigation, vol. 100, no. 12, pp. 3005-3013, 1997.

[41] N. R. Stob, C. Bell, M. A. van Baak, and D. R. Seals, "Thermic effect of food and $\beta$-adrenergic thermogenic responsiveness in habitually exercising and sedentary healthy adult humans," Journal of Applied Physiology, vol. 103, no. 2, pp. 616-622, 2007.

[42] T. Hayakawa, Y. Nagai, T. Kahara et al., "Gln27Glu and Arg16Gly polymorphisms of the $\beta 2$-adrenergic receptor gene are not associated with obesity in Japanese men," Metabolism, vol. 49, no. 9, pp. 1215-1218, 2000.

[43] H. Jia, P. Sharma, R. Hopper, C. Dickerson, D. D. Lloyd, and M. J. Brown, " $\beta 2$-adrenoceptor gene polymorphisms and blood pressure variations in East Anglian Caucasians," Journal of Hypertension, vol. 18, no. 6, pp. 687-693, 2000.

[44] H.-G. Xie, C. M. Stein, R. B. Kim et al., "Human $\beta 2-$ adrenergic receptor polymorphisms: no association with essential hypertension in black or white Americans," Clinical Pharmacology and Therapeutics, vol. 67, no. 6, pp. 670-675, 2000.

[45] G. Candy, N. Samani, G. Norton et al., "Association analysis of $\beta 2$ adrenoceptor polymorphisms with hypertension in a Black African population," Journal of Hypertension, vol. 18, no. 2, pp. 167-172, 2000.

[46] J. R. Cockcroft, A. G. Gazis, D. J. Cross et al., “ $\beta 2-$ adrenoceptor polymorphism determines vascular reactivity in humans," Hypertension, vol. 36, no. 3, pp. 371-375, 2000.

[47] A. Meirhaeghe, N. Helbecque, D. Cottel, and P. Amouyel, "Impact of polymorphisms of the human $\beta 2$-adrenoceptor gene on obesity in a French population," International Journal of Obesity, vol. 24, no. 3, pp. 382-387, 2000.

[48] N. Kato, T. Sugiyama, H. Morita et al., "Association analysis of $\beta 2$-adrenergic receptor polymorphisms with hypertension in Japanese," Hypertension, vol. 37, no. 2, pp. 286-292, 2001.

[49] K. Bengtsson, M. Orho-Melander, O. Melander et al., " $\beta 2$ adrenergic receptor gene variation and hypertension in subjects with type 2 diabetes," Hypertension, vol. 37, no. 5, pp. 1303-1308, 2001.

[50] D. L. Ellsworth, S. A. Coady, W. Chen et al., "Influence of the $\beta 2$-adrenergic receptor Arg16Gly polymorphism on longitudinal changes in obesity from childhood through young adulthood in a biracial cohort: the Bogalusa heart study," International Journal of Obesity, vol. 26, no. 7, pp. 928-937, 2002.

[51] S.-H. Kim, D.-J. Kim, I. A. Seo et al., "Significance of $\beta 2-$ adrenergic receptor gene polymorphism in obesity and type 2 diabetes mellitus in Korean subjects," Metabolism, vol. 51, no. 7, pp. 833-837, 2002.

[52] T.-J. Chang, M.-H. Tsai, Y.-D. Jiang et al., “The Arg16Gly polymorphism of human $\beta 2$-adrenoreceptor is associated with type 2 diabetes in Taiwanese people," Clinical Endocrinology, vol. 57, no. 5, pp. 685-690, 2002.

[53] C. T. M. Van Rossum, B. Hoebee, J. C. Seidell et al., "Genetic factors as predictors of weight gain in young adult Dutch men and women," International Journal of Obesity, vol. 26, no. 4, pp. 517-528, 2002.

[54] C. Garenc, L. Pérusse, Y. C. Chagnon et al., "Effects of $\beta 2$-adrenergic receptor gene variants on adiposity: the HERITAGE Family Study," Obesity Research, vol. 11, no. 5, pp. 612-618, 2003.

[55] F. Galletti, R. Iacone, E. Ragone et al., "Lack of association between polymorphism in the $\beta 2$ - adrenergic receptor gene, hypertension, and obesity in the Olivetti heart study," American Journal of Hypertension, vol. 17, no. 8, pp. 718-720, 2004.

[56] T. Ikarashi, O. Hanyu, S. Maruyama et al., "Genotype Gly/Gly of the Arg16Gly polymorphism of the $\beta 2$-adrenergic receptor is associated with elevated fasting serum insulin concentrations, but not with acute insulin response to glucose, in type 2 diabetic patients," Diabetes Research and Clinical Practice, vol. 63, no. 1, pp. 11-18, 2004.

[57] J. Tafel, I. Branscheid, B. Skwarna et al., "Variants in the human $\beta 1$-, $\beta 2$ - and $\beta$ 3-adrenergic receptor genes are not associated with morbid obesity in children and adolescents," Diabetes, Obesity and Metabolism, vol. 6, no. 6, pp. 452-455, 2004.

[58] D. L. Ellsworth, S. A. Coady, W. Chen, S. R. Srinivasan, E. Boerwinkle, and G. S. Berenson, "Interactive effects between polymorphisms in the $\beta$-adrenergic receptors and longitudinal changes in obesity," Obesity Research, vol. 13, no. 3, pp. 519-526, 2005.

[59] I. C. Trombetta, L. T. Batalha, M. U. P. B. Rondon et al., "Gly16 + Glu27 $\beta 2$-adrenoceptor polymorphisms cause increased forearm blood flow responses to mental stress and handgrip in humans," Journal of Applied Physiology, vol. 98, no. 3, pp. 787-794, 2005.

[60] K. Masuo, T. Katsuya, Y. Fu, H. Rakugi, T. Ogihara, and M. L. Tuck, " $\beta 2$-adrenoceptor polymorphisms relate to insulin resistance and sympathetic overactivity as early markers of metabolic disease in nonobese, normotensive individuals," American Journal of Hypertension, vol. 18, no. 7, pp. 10091014, 2005.

[61] K. Masuo, T. Katsuya, H. Kawaguchi et al., “ $\beta 2$-adrenoceptor polymorphisms relate to obesity through blunted leptinmediated sympathetic activation," American Journal of Hypertension, vol. 19, no. 10, pp. 1084-1091, 2006.

[62] H. Kawaguchi, K. Masuo, T. Katsuya et al., “ $\beta 2$ - and $\beta 3$ adrenoceptor polymorphisms relate to subsequent weight gain and blood pressure elevation in obese normotensive individuals," Hypertension Research, vol. 29, no. 12, pp. 951959, 2006.

[63] T. Kurabayashi, T. Yahata, J. Quan, and K. Tanaka, “Association of polymorphisms in the $\beta 2$ and $\beta 3$ adrenoceptor gene with polycystic ovary syndrome," Journal of Reproductive Medicine, vol. 51, no. 5, pp. 389-393, 2006. 
[64] A. P. Gjesing, G. Andersen, K. S. Burgdorf et al., "Studies of the associations between functional $\beta 2$ - adrenergic receptor variants and obesity, hypertension and type 2 diabetes in 7,808 white subjects," Diabetologia, vol. 50, no. 3, pp. 563$568,2007$.

[65] K. Masuo, T. Katsuya, K. Sugimoto et al., "High plasma norepinephrine levels associated with $\beta 2$-adrenoceptor polymorphisms predict future renal damage in nonobese normotensive individuals," Hypertension Research, vol. 30, no. 6, pp. 503-511, 2007.

[66] S. M. Echwald, T. I. A. Sørensen, A. Tybjærg-Hansen, T. Andersen, and O. Pedersen, "Gln27Glu variant of the human $\beta 2$-adrenoreceptor gene is not associated with early-onset obesity in Danish men," Diabetes, vol. 47, no. 10, pp. 1657$1658,1998$.

[67] L. Hellström, V. Large, S. Reynisdottir, H. Wahrenberg, and P. Arner, "The different effects of a Gln27Glu $\beta 2$-adrenoceptor gene polymorphism on obesity in males and in females," Journal of Internal Medicine, vol. 245, no. 3, pp. 253-259, 1999.

[68] B. Kortner, A. Wolf, D. Wendt, U. Beisiegel, and D. Evans, "Lack of association between a human $\beta$-2 adrenoceptor gene polymorphism (Gln27Glu) and morbid obesity," International Journal of Obesity, vol. 23, no. 10, pp. 1099-1100, 1999.

[69] T. Kawamura, G. Egusa, R. Fujikawa, and M. Okubo, "Gln27Glu variant of the $\beta 2$-adrenergic receptor gene is not associated with obesity and diabetes in Japanese-Americans," Metabolism, vol. 50, no. 4, pp. 443-446, 2001.

[70] O. Ukkola, A. Tremblay, and C. Bouchard, "Beta-2 adrenergic receptor variants are associated with subcutaneous fat accumulation in response to long-term overfeeding," International Journal of Obesity, vol. 25, no. 11, pp. 1604$1608,2001$.

[71] J. L. González Sánchez, A. M. Proenza, M. T. Martínez Larrad et al., "The glutamine 27 glutamic acid polymorphism of the $\beta 2$-adrenoceptor gene is associated with abdominal obesity and greater risk of impaired glucose tolerance in men but not in women: a population-based study in Spain," Clinical Endocrinology, vol. 59, no. 4, pp. 476-481, 2003.

[72] M. Rasmussen, A. Belza, T. Almdal et al., "Change in $\beta 1$ adrenergic receptor protein concentration in adipose tissue correlates with diet-induced weight loss," Clinical Science, vol. 108, no. 4, pp. 323-329, 2005.

[73] Y. Linné, I. Dahlman, and J. Hoffstedt, “ $\beta 1$-adrenoceptor gene polymorphism predicts long-term changes in body weight," International Journal of Obesity, vol. 29, no. 5, pp. 458-462, 2005.

[74] M. Rydén, J. Hoffstedt, P. Eriksson, S. Bringman, and P. Arner, "The Arg389gly $\beta 1$-adrenergic receptor gene polymorphism and human fat cell lipolysis," International Journal of Obesity, vol. 25, no. 11, pp. 1599-1603, 2001.

[75] A. P. Gjesing, G. Andersen, A. Albrechtsen et al., "Studies of associations between the Arg389Gly polymorphism of the $\beta 1$-adrenergic receptor gene (ADRB1) and hypertension and obesity in 7677 Danish white subjects," Diabetic Medicine, vol. 24, no. 4, pp. 392-397, 2007.

[76] K. Clement, C. Vaisse, B. S. J. Manning et al., "Genetic variation in the $\beta 3$-adrenergic receptor and an increased capacity to gain weight in patients with morbid obesity," The New England Journal of Medicine, vol. 333, no. 6, pp. 352-354, 1995.

[77] E. Widen, M. Lehto, T. Kanninen, J. Walston, A. R. Shuldiner, and L. C. Groop, "Association of a polymorphism in the $\beta 3$-adrenergic-receptor gene with features of the insulin resistance syndrome in finns," The New England Journal of Medicine, vol. 333, no. 6, pp. 348-351, 1995.

[78] J. Walston, K. Silver, C. Bogardus et al., "Time of onset of non-insulin-dependent diabetes mellitus and genetic variation in the $\beta 3$-adrenergic-receptor gene," The New England Journal of Medicine, vol. 333, no. 6, pp. 343-347, 1995.

[79] T. Fujisawa, H. Ikegami, E. Yamato et al., "Association of Trp64Arg mutation of the $\beta 3$-adrenergic-receptor with NIDDM and body weight gain," Diabetologia, vol. 39, no. 3, pp. 349-352, 1996.

[80] K. Silver, J. Walston, Y. Wang, G. Dowse, P. Zimmet, and A. R. Shuldiner, "Molecular scanning for mutations in the $\beta 3$-adrenergic receptor gene in nauruans with obesity and noninsulin-dependent diabetes mellitus," Journal of Clinical Endocrinology and Metabolism, vol. 81, no. 11, pp. 41554158, 1996.

[81] T. Fujisawa, H. Ikegami, E. Yamato et al., “Trp64Arg mutation of $\beta 3$-adrenergic receptor in essential hypertension. Insulin resistance and the adrenergic system," American Journal of Hypertension, vol. 10, no. 1, pp. 101-105, 1997.

[82] N. Sakane, T. Yoshida, T. Umekawa, M. Kondo, Y. Sakai, and T. Takahashi, " $\beta 3$-adrenergic-receptor polymorphism: a genetic marker for visceral fat obesity and the insulin resistance syndrome," Diabetologia, vol. 40, no. 2, pp. 200204, 1997.

[83] J. Rissanen, M. Kuopusjärvi, J. Pihlajamäki et al., "The Trp64Arg polymorphism of the $\beta 3$-adrenergic receptor gene: lack of association with NIDDM and features of insulin resistance syndrome," Diabetes Care, vol. 20, no. 8, pp. 13191323, 1997.

[84] N. McFarlane-Anderson, F. Bennett, R. Wilks et al., "The Trp64Arg mutation of the $\beta 3$-adrenergic receptor is associated with hyperglycemia and current body mass index in Jamaican women," Metabolism, vol. 47, no. 5, pp. 617-621, 1998.

[85] E. García-Rubi, R. D. Starling, A. Tchernof et al., “Trp64Arg variant of the $\beta 3$-adrenoceptor and insulin resistance in obese postmenopausal women," Journal of Clinical Endocrinology and Metabolism, vol. 83, no. 11, pp. 40024005, 1998.

[86] J. A. M. J. L. Janssen, J. W. Koper, R. P. Stolk et al., "Lack of associations between serum leptin, a polymorphism in the gene for the $\beta 3$-adrenergic receptor and glucose tolerance in the Dutch population," Clinical Endocrinology, vol. 49, no. 2, pp. 229-234, 1998.

[87] K. Shiwaku, T. Q. Gao, A. Isobe, T. Fukushima, and Y. Yamane, "A Trp64Arg mutation in the $\beta 3$-adrenergic receptor gene is not associated with moderate overweight in Japanese workers," Metabolism, vol. 47, no. 12, pp. 1528-1530, 1998.

[88] B. Ongphiphadhanakul, R. Rajatanavin, S. Chanprasertyothin et al., "Relation of $\beta 3$-adrenergic receptor gene mutation to total body fat but not percent body fat and insulin levels in Thais," Metabolism, vol. 48, no. 5, pp. 564567, 1999.

[89] A. Pulkkinen, A. Kareinen, L. Saarinen, S. Heikkinen, S. Lehto, and M. Laakso, "The codon 64 polymorphism of the $\beta 3$-adrenergic receptor gene is not associated with coronary heart disease or insulin resistance in nondiabetic subjects and non-insulin-dependent diabetic patients," Metabolism, vol. 48, no. 7, pp. 853-856, 1999.

[90] C. Christiansen, P. Poulsen, and H. Beck-Nielsen, "The Trp64Arg mutation of the adrenergic $\beta-3$ receptor gene 
impairs insulin secretion: a twin study," Diabetic Medicine, vol. 16, no. 10, pp. 835-840, 1999.

[91] K. Stangl, I. Cascorbi, M. Laule et al., "The $\beta 3$-adrenergic receptor Trp64Arg mutation is not associated with coronary artery disease," Metabolism, vol. 50, no. 2, pp. 184-188, 2001.

[92] P. Strazzullo, R. Iacone, A. Siani et al., "Relationship of the Trp64Arg polymorphism of the beta3-adrenoceptor gene to central adiposity and high blood pressure: interaction with age. Cross-sectional and longitudinal findings of the Olivetti prospective heart study," Journal of Hypertension, vol. 19, no. 3, pp. 399-406, 2001.

[93] T. Ishii, H. Hirose, T. Kawai et al., "Effects of intestinal fatty acid-binding protein gene Ala54Thr polymorphism and $\beta 3$ adrenergic receptor gene Trp64Arg polymorphism on insulin resistance and fasting plasma glucose in young to older Japanese men," Metabolism, vol. 50, no. 11, pp. 1301-1307, 2001.

[94] N. Kurokawa, K. Nakai, S. Kameo, Z.-M. Liu, and H. Satoh, "Association of BMI with the $\beta 3$-adrenergic receptor gene polymorphism in Japanese: meta-analysis," Obesity Research, vol. 9, no. 12, pp. 741-745, 2001.

[95] M. C. Ochoa, A. Marti, C. Azcona et al., "Gene-gene interaction between PPAR $\gamma 2$ and ADR $\beta 3$ increases obesity risk in children and adolescents," International Journal of Obesity, vol. 28, supplement 3, pp. S37-S41, 2004.

[96] P. I. Porto, S. I. García, G. Dieuzeide, C. González, M. S. Landa, and C. J. Pirola, "Clinical features of the metabolic syndrome in adolescents: minor role of the Trp64Arg $\beta 3$ adrenergic receptor gene variant," Pediatric Research, vol. 55, no. 5, pp. 836-841, 2004.

[97] P.-J. Tsai, L.-P. Tsai, Y.-H. Lee et al., "Lack of relationship between $\beta 3$-adrenergic receptor gene polymorphism and gestational diabetes mellitus in a Taiwanese population," Metabolism, vol. 53, no. 9, pp. 1136-1139, 2004.

[98] K. Højlund, C. Christiansen, K. S. Bjørnsbo et al., "Energy body composition and insulin response to glucose in male twins discordant for the Trp64Arg polymorphism of the $\beta 3$ adrenergic receptor gene," Diabetes, Obesity and Metabolism, vol. 8, no. 3, pp. 322-330, 2006.

[99] S. Tamaki, Y. Nakamura, Y. Tabara et al., "Relationship between metabolic syndrome and Trp64Arg polymorphism of the $\beta 3$-adrenergic receptor gene in a general sample: the Shigaraki study," Hypertension Research, vol. 29, no. 11, pp. 891-896, 2006.

[100] S. Morcillo, F. Cardona, G. Rojo-Martínez et al., "Effect of the combination of the variants -75G/A APOA1 and Trp64Arg ADRB3 on the risk of type 2 diabetes (DM2)," Clinical Endocrinology, vol. 68, no. 1, pp. 102-107, 2008.

[101] A. P. Gjesing, G. Andersen, K. Borch-Johnsen, T. Jørgensen, T. Hansen, and O. Pedersen, "Association of the $\beta 3$ adrenergic receptor Trp64Arg polymorphism with common metabolic traits: studies of 7605 middle-aged white people," Molecular Genetics and Metabolism, vol. 94, no. 1, pp. 90-97, 2008.

[102] K. Dunajska, F. Lwow, A. Milewicz et al., " $\beta 3$-adrenergic receptor polymorphism and metabolic syndrome in postmenopausal women," Gynecological Endocrinology, vol. 24, no. 3, pp. 133-138, 2008.

[103] T. J. Maxwell, M. M. Ameyaw, S. Pritchard et al., "Beta-2 adrenergic receptor genotypes and haplotypes in different ethnic groups," International Journal of Molecular Medicine, vol. 16, no. 4, pp. 573-580, 2005.
[104] H. Schelleman, B. H. Stricker, A. De Boer et al., "Drug-gene interactions between genetic polymorphisms and antihypertensive therapy," Drugs, vol. 64, no. 16, pp. 1801-1816, 2004.

[105] J. Hoffstedt, O. Poirier, A. Thörne et al., "Polymorphism of the human $\beta 3$-adrenoceptor gene forms a well-conserved haplotype that is associated with moderate obesity and altered receptor function," Diabetes, vol. 48, no. 1, pp. 203205, 1999.

[106] A. Sandilands, G. Yeo, M. J. Brown, and K. M. O'Shaughnessy, "Functional responses of human $\beta 1$ adrenoceptors with defined haplotypes for the common $389 \mathrm{R}>\mathrm{G}$ and 49S >G polymorphisms," Pharmacogenetics, vol. 14, no. 6, pp. 343-349, 2004.

[107] M. Tomaszewski, N. J. R. Brain, F. J. Charchar et al., "Essential hypertension and $\beta 2$-adrenergic receptor gene: linkage and association analysis," Hypertension, vol. 40, no. 3, pp. 286291, 2002.

[108] S. A. Green, J. Turki, M. Innis, and S. B. Liggett, "Aminoterminal polymorphisms of the human $\beta 2$-adrenergic receptor impart distinct agonist-promoted regulatory properties," Biochemistry, vol. 33, no. 32, pp. 9414-9419, 1994.

[109] V. Dishy, G. G. Sofowora, H.-G. Xie et al., "The effect of common polymorphisms of the $\beta 2$-adrenergic receptor on agonist-mediated vascular desensitization," The New England Journal of Medicine, vol. 345, no. 14, pp. 1030-1035, 2001.

[110] G. Gratze, J. Fortin, R. Labugger et al., “ $\beta$-2 adrenergic receptor variants affect resting blood pressure and agonist-induced vasodilation in young adult Caucasians," Hypertension, vol. 33, no. 6, pp. 1425-1430, 1999.

[111] B. D. Hoit, D. P. Suresh, L. Craft, R. A. Walsh, and S. B. Liggett, " $\beta 2$-adrenergic receptor polymorphisms at amino acid 16 differentially influence agonist-stimulated blood pressure and peripheral blood flow in normal individuals," American Heart Journal, vol. 139, no. 3, pp. 537-542, 2000.

[112] C. Bell, N. R. Stob, and D. R. Seals, "Thermogenic responsiveness to nonspecific $\beta$-adrenergic stimulation is not related to genetic variation in codon 16 of the $\beta 2$-adrenergic receptor," American Journal of Physiology, vol. 290, no. 4, pp. E703E707, 2006.

[113] A. P. Gjesing, G. Andersen, K. S. Burgdorf et al., "Studies of the associations between functional $\beta 2$ - adrenergic receptor variants and obesity, hypertension and type 2 diabetes in 7,808 white subjects," Diabetologia, vol. 50, no. 3, pp. 563$568,2007$.

[114] P. Arner, "The $\beta 3$-adrenergic receptor-a cause and cure of obesity?" The New England Journal of Medicine, vol. 333, no. 6, pp. 382-383, 1995.

[115] S. Enocksson, M. Shimizu, F. Lonnqvist, J. Nordenstrom, and P. Arner, "Demonstration of an in vivo functional $\beta 3$ adrenoceptor in man," Journal of Clinical Investigation, vol. 95, no. 5, pp. 2239-2245, 1995.

[116] Y. T. Yang and M. A. McElligott, "Multiple actions of $\beta$ adrenergic agonists on skeletal muscle and adipose tissue," Biochemical Journal, vol. 261, no. 1, pp. 1-10, 1989.

[117] T. Oizumi, M. Daimon, T. Saitoh et al., "Genotype Arg/Arg, but not Trp/Arg, of the Trp64Arg polymorphism of the $\beta 3$ adrenergic receptor is associated with type 2 diabetes and obesity in a large Japanese sample," Diabetes Care, vol. 24, no. 9, pp. 1579-1583, 2001. 


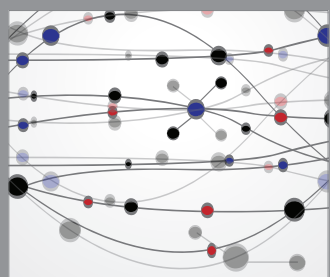

The Scientific World Journal
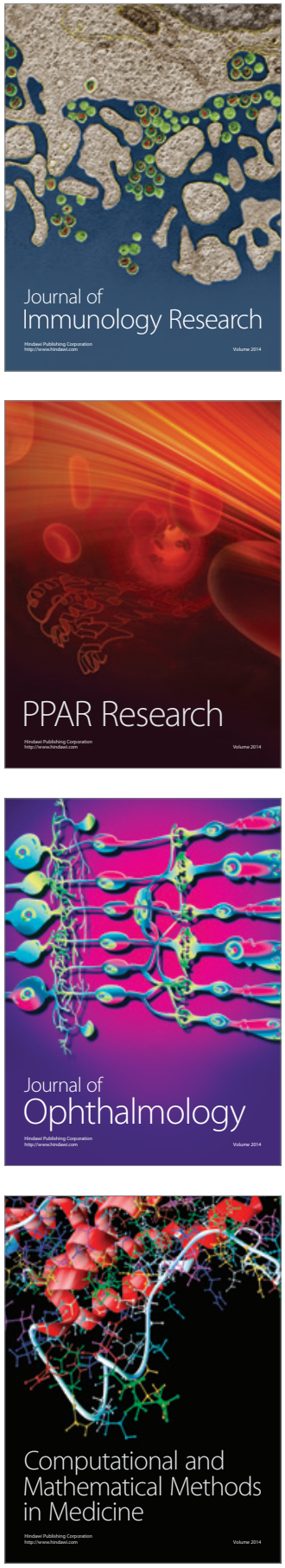

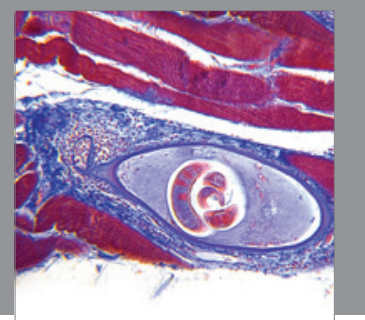

Gastroenterology

Research and Practice
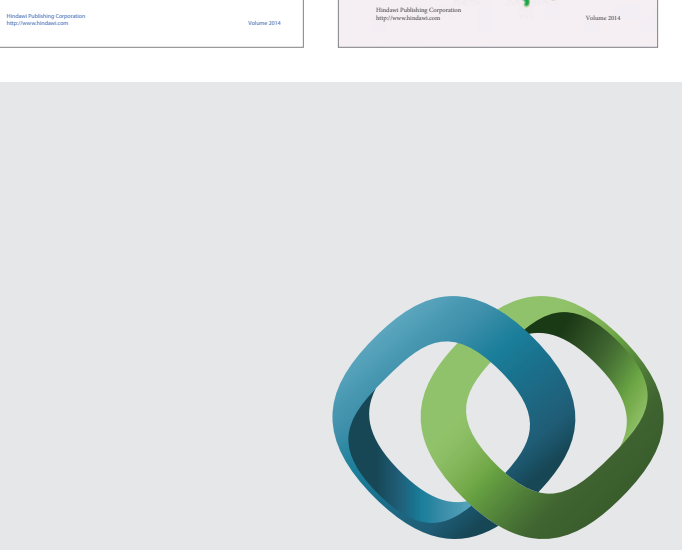

\section{Hindawi}

Submit your manuscripts at

http://www.hindawi.com
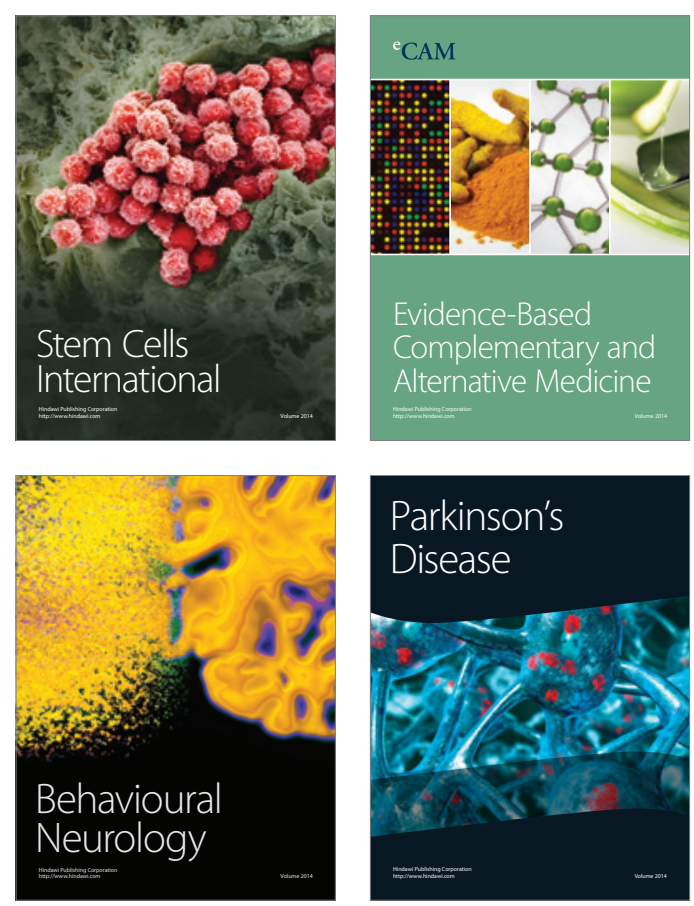

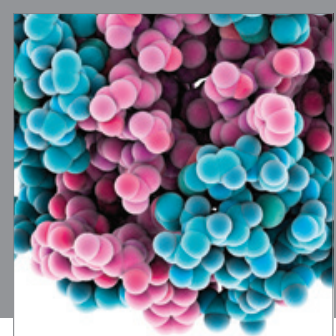

Journal of
Diabetes Research

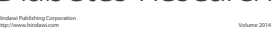

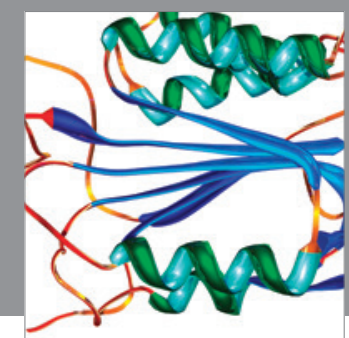

Disease Markers
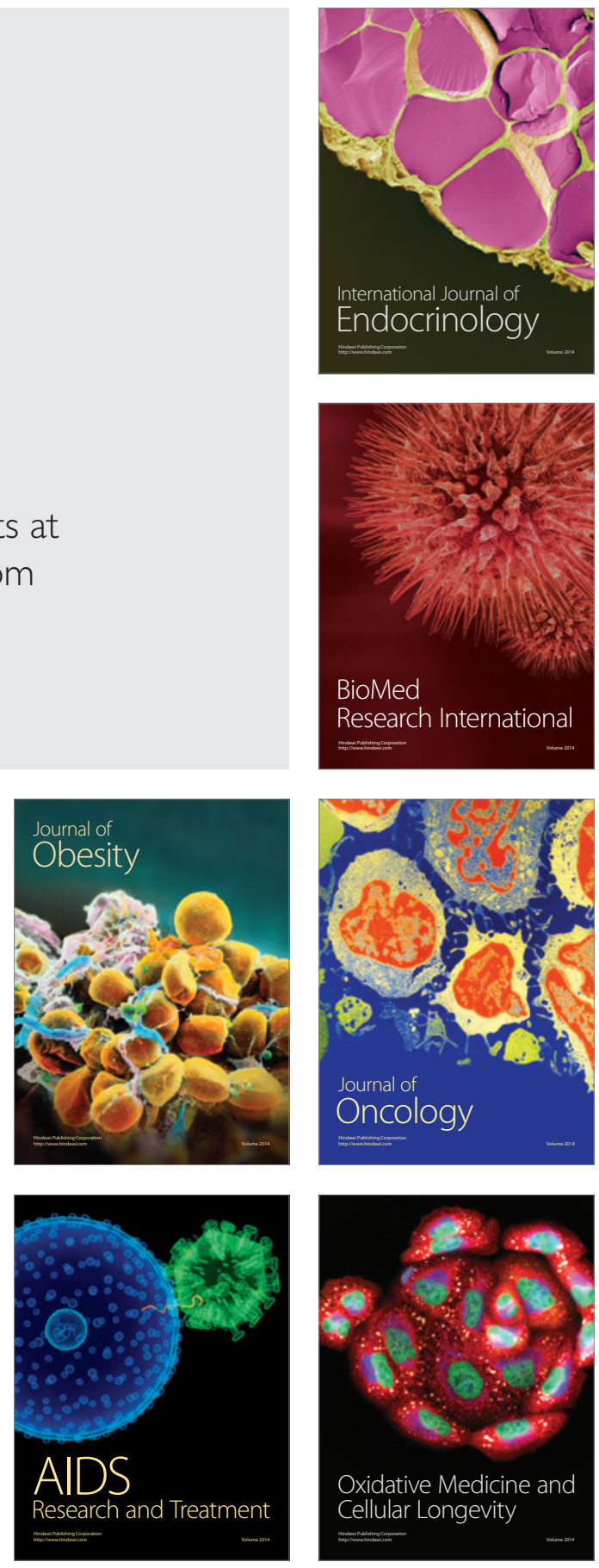